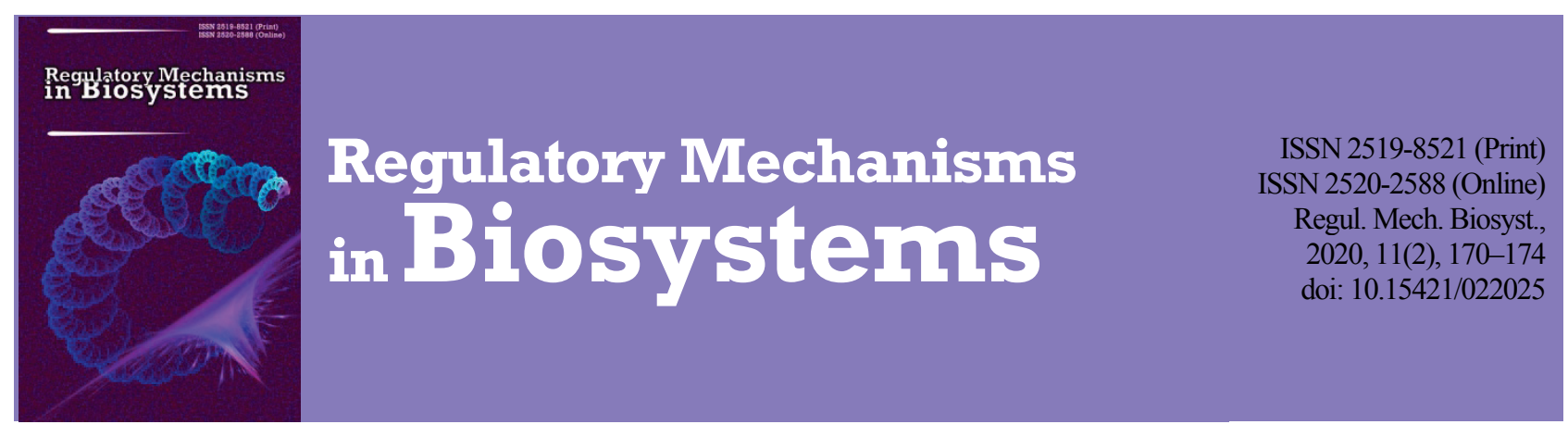

\title{
Effect of abiotic factors on sulfidogenic activity of bacteria Desulfuromonas sp.
}

\author{
O. M. Chaika, T. B. Peretyatko \\ Ivan Franko National University of Lviv, Lviv, Ukraine
}

Article info

Received 28.03.2020

Received in revised form

22.04.2020

Accepted 24.04.2020

\author{
Chaika, O. M., \& Peretyatko, T. B. (2020). Effect of abiotic factors on sulfidogenic activity of bacteria Desulfuromonas sp. Regu- \\ latory Mechanisms in Biosystems, 11(2), 170-174. doi:10.15421/022025
}

Ivan Franko

National University

of Lviv, Hrushevsky st., 4,

Lviv, 79005, Ukraine.

Tel.: +38-093-799-12-11.

E-mail:

ochayka13@gmail.com

Sulfur-reducing bacteria are promising agents for the development of new methods of wastewater treatment with the removal of ions of heavy metals and organic compounds. Study of the effect of various environmental factors on the growth and sulfidogenic activity of sulfur-reducing bacteria allows one to investigate the adaptability of these microorganisms to stress factors. The paper deals with the effect of $\mathrm{pH}$, different concentrations of elemental sulfur, hydrogen sulfide and presence of various electron acceptors on the growth and sulfidogenic activity of bacteria Desulfuromonas sp. YSDS-3. The calculation of C/S ratio for sulfur-reducing bacteria Desulfuromonas sp. YSDS-3 was made, with the comparison with similar parameters of sulfate-reducing bacteria. In the medium with elemental sulfur, concentration of hydrogen sulfide increased with the concentration of elemental sulfur. Bacteria $D e-$ sulfuromonas sp. YSDS-3 accumulated their biomass in the most effective way at the concentration of elemental sulfur of 10 $100 \mathrm{mM}$. In the medium with polysulfide form of sulfur at the neutral $\mathrm{pH}$, bacteria produced hydrogen sulfide and accumulated biomass the best. Hydrogen sulfide at the concentration of $3 \mathrm{mM}$ did not inhibit the bacterial growth, but further increase in the hydrogen sulfide concentration inhibited the growth of bacteria. The bacteria did not grow at the hydrogen sulfide concentration of $25 \mathrm{mM}$ and above. As the concentration of elemental sulfur and cell density increases, sulfidogenic activity of the bacteria grows. Presence of two electron acceptors ( $\mathrm{S}$ and $\mathrm{K}_{2} \mathrm{Cr}_{2} \mathrm{O}_{7}, \mathrm{~S}$ and $\mathrm{MnO}_{2}, \mathrm{~S}$ and $\mathrm{Fe}$ (III)) did not affect the accumulation of biomass of the bacteria Desulfuromonas sp. YSDS-3. However, under such conditions the bacteria accumulated 1.5-2.5 times less hydrogen sulfide than in the test medium. After 12-24 h of cultivation, different concentrations of elemental sulfur had a significant effect on the sulfidogenic activity. However, during 3-16 days of cultivation, the percentage of effect of elemental sulfur concentration decreased to $31 \%$, while the percentage of effect of cell density increased threefold. Presence in the medium of the electron acceptors ( $\mathrm{Cr}(\mathrm{VI}), \mathrm{MnO}_{2}, \mathrm{Fe}$ (III)) alternative to elemental sulfur led to a significant decrease in the content of hydrogen sulfide produced by sulfur-reducing bacteria.

Keywords: sulfur-reducing bacteria; hydrogen sulfide; elemental sulfur; polysulfide; electron donor; electron acceptor.

\section{Introduction}

Microorganisms play an important role in the biosphere, in particular, in the processes of biotransformation of organic and inorganic substances, biogeochemical cycles of metallic and non-metallic elements, transformation of metals, minerals, soil and sediment formation (Bertrand et al., 2014; Liet et al., 2018; Crane, 2019). Sulfur-reducing bacteria attract the attention of researchers as potential agents for the treatment of wastewater contaminated with sulfur and sulfur compounds, ions of heavy metals and organic compounds. By performing dissimilation recovery of sulfur, sulfur-reducing bacteria oxidize various organic compounds, thus purifying water reservoirs from organic matter (Qiuet et al., 2017; Moroz et al., 2018). These bacteria oxidize various organic substrates using metals of variable valency as electron acceptors and turn them into forms which are non-toxic or less toxic for living organisms (Smith \& Gadd, 1993). Sulfur-reducing bacteria resistant to high concentrations of heavy metal ions are involved in the reduction deposition of toxic metal ions. Usage of these microorganisms can neutralize the toxicity of the hydrogen sulfide produced by them and heavy metal ions due to their binding to produce insoluble sulfides (Lovley, 2004; Qiuet et al., 2017; Suna et al., 2020). A number of studies have been conducted to investigate sulfidogenic systems based on sulfate-reducing bacteria, which were used for the purification of wastewaters from heavy metal ions; their effectiveness compared to chemical methods is confirmed. However, it is found that sulfidogenic processes caused by sulfur-reducing bacteria are more cost effective in wastewater treatment than conventional systems of sulfate ion treatment (Qiu et al., 2017; Su- na et al., 2020). It is suggested that elemental sulfur is a good alternative to sulfate ions since only two electrons are required for sulfur reduction, as distinct from the eight-electron process of sulfate ion reduction (Suna et al., 2020). Sulfur-reducing bacteria are highly efficient biocatalysts of microbial anodic fuel cells, which provide the electric current generation during oxidation of organic compounds (Logan \& Regan, 2006). Carbohydrates (glucose, sucrose, cellulose, starch), volatile fatty acids (formiate, acetate, butyrate), alcohols (ethanol, methanol), amino acids, proteins and even inorganic components (Alves et al., 2011; Richter et al., 2012; Vasyliv et al., 2015; Knoche et al., 2016) are used to generate the electric current in the microbial anodic fuel cells.

Sulfur-reducing bacteria attract the attention of researchers as potential agents for the purification of wastewater from the compounds of sulfur, heavy metal ions and organic compounds. However, the role of sulfur-reducing bacteria for the purification of wastewaters from heavy metal ions has been little investigated. Hydrogen sulfide accumulation efficiency is influenced by the various environmental factors, such as $\mathrm{pH}$, hydrogen sulfide, presence of various donors and acceptors of electrons, concentration of heavy metal ions etc. (An \& Picardal, 2015; Moroz et al., 2018). The objective of this work consisted in the evaluation of the effect of abiotic factors of the medium on sulfidogenic activity of bacteria Desulfuromonas sp.

\section{Materials and methods}

Sulfur-reducing bacteria Desulfuromonas sp. YSDS-3 isolated from soil of Yazivsky sulfur deposit (Yavorivsky district, L'viv region, Ukra- 
ine) (Chayka et al., 2018) were used in the work. Bacteria were grown in the modified Postgate $\mathrm{C}$ medium with the composition as follows $(\mathrm{g} / \mathrm{L})$ : $\mathrm{KH}_{2} \mathrm{PO}_{4}-0.5, \mathrm{NH}_{4} \mathrm{Cl}-1.0, \mathrm{CaCl}_{2} \bullet 6 \mathrm{H}_{2} \mathrm{O}-0.06, \mathrm{MgCl}_{2} \bullet 6 \mathrm{H}_{2} \mathrm{O}-0.05$, sodium lactate -6.0 , yeast extract -1.0 , sodium citrate -0.3 , ascorbic acid - 1.0; elemental sulfur - 1.0, distilled water - up to $1 \mathrm{~L}, \mathrm{pH} 7.5$ (Postgate, 1984). The medium was sterilized at 0.75 atm during 30 minutes, poured into test tubes $(25 \mathrm{~mL})$, and closed with sterile rubber stoppers. The medium was inoculated with a suspension of cells at the concentration of $0.2 \mathrm{~g} / \mathrm{L}$ and cultured at $30^{\circ} \mathrm{C}$ during 5-14 days. Generators GENboxanaer (France) were used to absorb oxygen. The conditions of anaerobiosis were confirmed with the use of anaerobic conditions' indicator AnaerIndicator (bioMeriux, France). Cell biomass was determined by turbidimetric method on the photoelectric colorimeter КФК $-3(\lambda=$ $340 \mathrm{~nm}$, cuvette length $-3 \mathrm{~mm}$ ). Content of hydrogen sulfide was found by photoelectric colorimetry method on the formation of methylene blue (Sugiyama, 2002). Content of $\mathrm{Cr}$ (VI), $\mathrm{Fe}$ (III), $\mathrm{Mn}$ (IV) and $\mathrm{NO}_{3}^{-}$in the culture liquid was determined using qualitative measurement (Harris, 2003). The initial concentration of cells in all experiments was equal to $0.2 \mathrm{~g} / \mathrm{L}$, and elemental sulfur - to $1 \mathrm{mM}$. Incubation lasted for 10 days.

For static processing of results, two-way analysis of variance with ANOVA function was used. It allows one to estimate the differences between sample averages for any number of samples. The obtained results were presented as mean \pm standard deviation $(\mathrm{x} \pm \mathrm{SD})$. The differences between samples were considered significant at $\mathrm{P}<0.05$ with Bonferroni correction.

\section{Results}

The largest biomass and the highest content of hydrogen sulfide during cultivation of bacteria Desulfuromonas sp. YSDS-3 in the medium with polysulfide sulfur was found at $\mathrm{pH}$ 7.5. At acid $\mathrm{pH}$ values (5 and 4) sulfidogenic activity decreased 3 and 7 times, accordingly (Fig. 1).

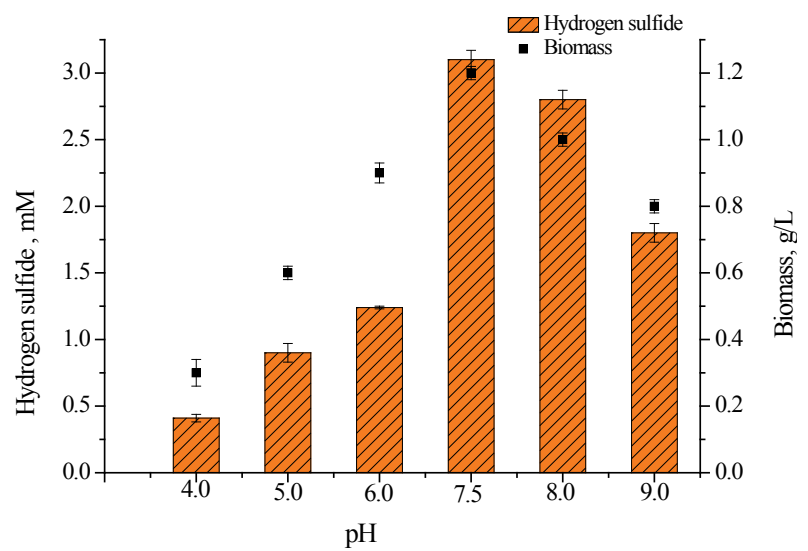

Fig. 1. The effect of $\mathrm{pH}$ to accumulation of hydrogen sulfide by bacteria Desulfuromonas sp. YSDS-3 in the presence of polysulfide $(\mathrm{x} \pm \mathrm{SD}, \mathrm{n}=5)$

During the cultivation of bacteria Desulfuromonas sp. YSDS-3 in the medium with elemental sulfur, the hydrogen sulfide concentration increased with the growth of elemental sulfur concentration (Fig. 2); maximum hydrogen sulfide concentration is $5.4 \mathrm{mM}$. At the concentration of elemental sulfur of $1000 \mathrm{mM}$ and above, biomass of bacteria halved. The most effective growth of bacteria was observed at the concentration of elemental sulfur of $10-100 \mathrm{mM}$.

In order to study the effect of hydrogen sulfide on the accumulation of biomass of bacteria Desulfuromonas sp. YSDS-3, they were cultured in Postgate $\mathrm{C}$ medium with fumarate without elemental sulfur; hydrogen sulfide was introduced in concentrations of $3,5,10,15,20,25,30$, $35 \mathrm{mM}$. Hydrogen sulfide in the concentration of $3 \mathrm{mM}$ did not inhibit the growth of bacteria Desulfuromonas sp. YSDS-3. Hydrogen sulfide concentrations of 5-20 mM were observed to inhibit the growth 1.5 and 3 times, respectively (Fig. 3). No growth of bacteria occurred at the hydrogen sulfide concentration of $25 \mathrm{mM}$ and more (Fig. 3). In the presence in the medium of two acceptors of electrons (of elemental sulfur
(1 mM) with $\mathrm{MnO}_{2}(1 \mathrm{Mm}), \mathrm{KNO}_{3}(5 \mathrm{mM})$, by iron (III) citrate $(5 \mathrm{mM})$ and potassium bichromate $(0.1 \mathrm{mM}))$, bacteria Desulfuromonas sp. YSDS-3 accumulated their biomass the best in the medium with $\mathrm{KNO}_{3}$ and $\mathrm{S}^{0}$. However, their sulfidogenic activity was 2.5 times lower compared to the control (Fig. 4). In the presence of $\mathrm{MnO}_{2}$, iron (III) citrate and potassium bichromate, bacteria Desulfuromonas sp. YSDS-3 accumulated the same biomass as in the test medium. Nevertheless, under such conditions, bacteria accumulated 1.5-2.0 times less hydrogen sulfide than in the test medium. Cr (VI), $\mathrm{Fe}$ (III), $\mathrm{Mn}$ (IV), $\mathrm{NO}_{3}{ }^{-}$ were not detected in the culture medium.

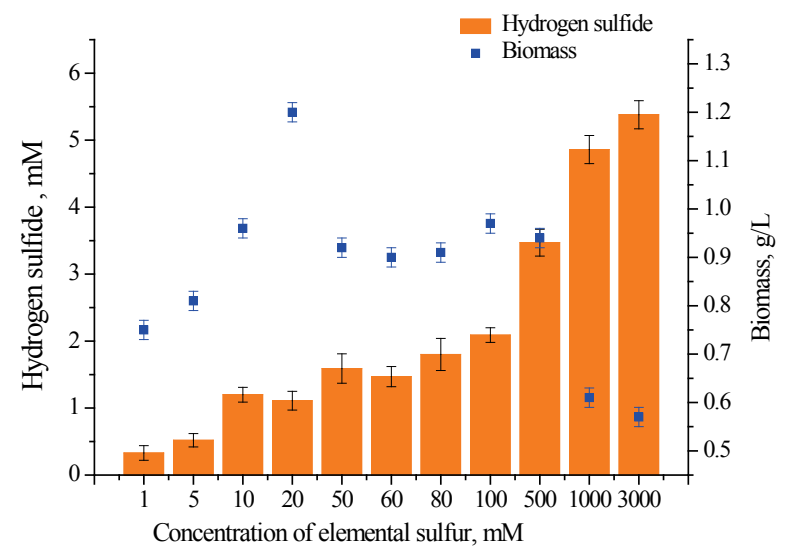

Fig. 2. The accumulation of hydrogen sulfide by bacteria Desulfuromonas sp. YSDS-3 in the presence of elemental sulfur: $\mathrm{x} \pm \mathrm{SD}, \mathrm{n}=5$

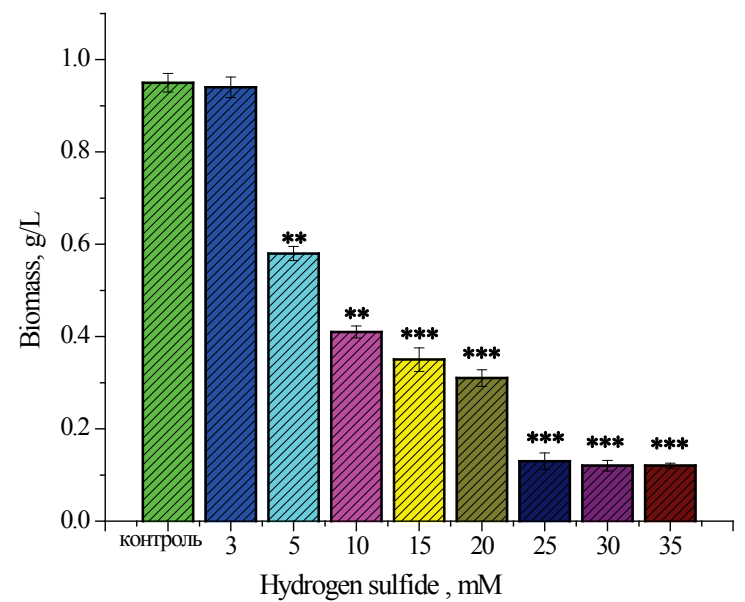

Fig. 3. The effect of hydrogen sulfide by bacteria Desulfuromonas sp. YSDS-3: ** $-\mathrm{P}<0.01, * * *-\mathrm{P}<0.001$ significant changes of biomass compared to control (with Bonferroni correction); $\mathrm{x} \pm \mathrm{SD}, \mathrm{n}=5$

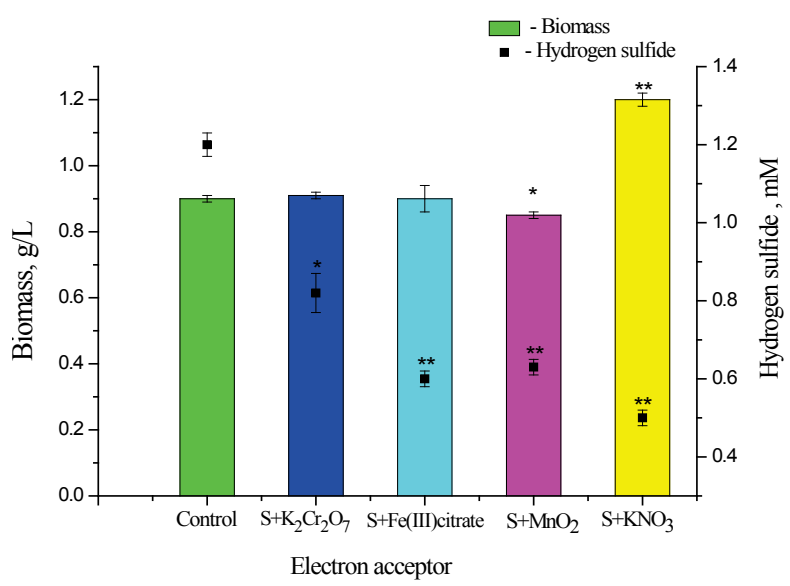

Fig. 4. Effect of different electron acceptors for the accumulation of biomass and hydrogen sulfide by bacteria Desulfuromonas sp. YSDS- 3 : * $-\mathrm{P}<0.05, * *-\mathrm{P}<0.01$ significant changes of biomass and hydrogen sulfide compared to control (with Bonferroni correction); $\mathrm{x} \pm \mathrm{SD}, \mathrm{n}=5$ 
$\mathrm{C} / \mathrm{S}$ ratio ( $\mathrm{mg}$ of oxidized organic carbon to $\mathrm{mg}$ of sulfide formed) for bacteria Desulfuromonas sp. YSDS-3 and sulfate-reducing bacteria Desulfotomaculum AR1 in the presence of elemental sulfur is 0.212 0.241 , which is 2.5 times less than for bacteria Desulfomicrobium sp. CrR3 and D. desulfuricans Ya-11.

Table 1

The ratio of $\mathrm{C} / \mathrm{S}$ after cultivation of sulfate and sulfur-reducing bacteria in media with sodium lactate $(\mathrm{x} \pm \mathrm{SD}, \mathrm{n}=5)$

\begin{tabular}{lcccc}
\hline \multicolumn{1}{c}{ Bacteria } & $\begin{array}{c}\text { Sulfur } \\
\text { source }\end{array}$ & $\begin{array}{c}\text { Biomass, } \\
\mathrm{g} / \mathrm{L}\end{array}$ & $\begin{array}{c}\text { Concentration of } \\
\text { hydrogen sulfide, } \\
\mathrm{mM}\end{array}$ & $\begin{array}{c}\mathrm{C} / \mathrm{S}^{*} \\
\text { ratio }\end{array}$ \\
\hline Desulfotomaculum $\mathrm{AR} 1$ & $\mathrm{~S}^{0}$ & $3.21 \pm 0.15$ & $16.12 \pm 0.71$ & 0.241 \\
Desulfomicrobium sp. CrR33 & $\mathrm{SO}_{4}^{2-}$ & $3.01 \pm 0.11$ & $14.11 \pm 0.64$ & 0.763 \\
D. desulfuricans Ya-11 & $\mathrm{SO}_{4}^{2-}$ & $2.41 \pm 0.12$ & $4.01 \pm 0.19$ & 0.582 \\
Desulfuromonas sp. YSDS-3 & $\mathrm{S}^{0}$ & $\begin{array}{c}1.31 \pm 0.06 \\
0.05\end{array}$ & $14.67 \pm 0.73$ & 0.665 \\
& & 0.05 & $3.20 \pm 0.15$ & 0.212 \\
\hline
\end{tabular}

Note: ${ }^{*} \mathrm{C} / \mathrm{S}$ ratios $-\mathrm{mg}$ of oxidized organic carbon to $\mathrm{mg}$ of produced sulfide.
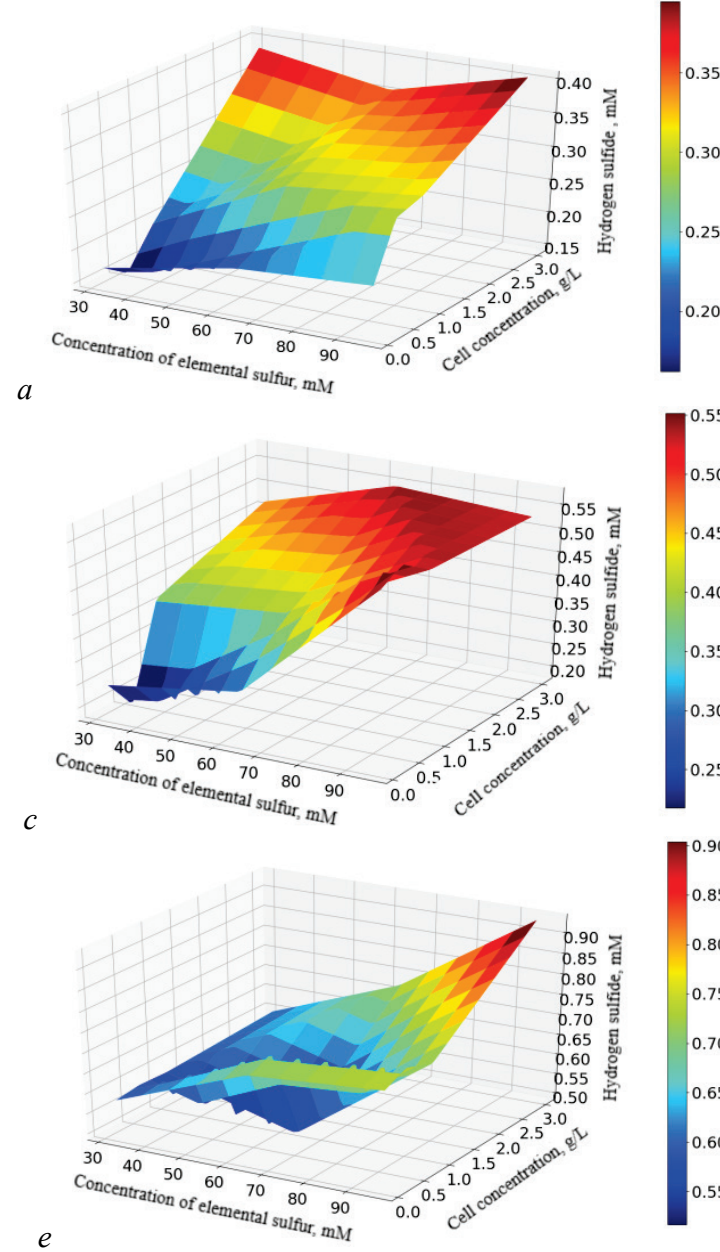

The effect of elemental sulfur at the concentration of 32,64 and $96 \mathrm{mM}$ and the initial cell concentration $(0.1,0.5,1.0$ and $3.0 \mathrm{~g} / \mathrm{L})$ on the sulfidogenic activity of bacteria Desulfuromonas sp. YSDS-3 was evaluated during 16 days of cultivation using two-way analysis. Six series of two-way analysis of variance were performed, with the results presented in Figure 5. As the concentration of elemental sulfur and cell density increases, sulfidogenic activity of the bacteria grows.

The relative proportions of the effect of different concentrations of elemental sulfur, different cell density and other unaccounted factors on the sulfidogenic activity of bacteria Desulfuromonas sp. YSDS-3 are shown in (Fig. 6).

After 12-24 hours of cultivation, the most significant effect on sulfidogenic activity was observed on the part of different concentrations of elemental sulfur. The percent of the effect is $73 \%$ after $12 \mathrm{~h}$ and $70 \%$ after $24 \mathrm{~h}$ of cultivation. However, within 3-16 days of cultivation, the percentage of effect of elemental sulfur concentration decreased to $31 \%$ and the percentage of effect of cell density increased from $17 \%$ to $57 \%$. The effect of other unaccounted factors was 3-13\% depending on duration of the bacterial cultivation.
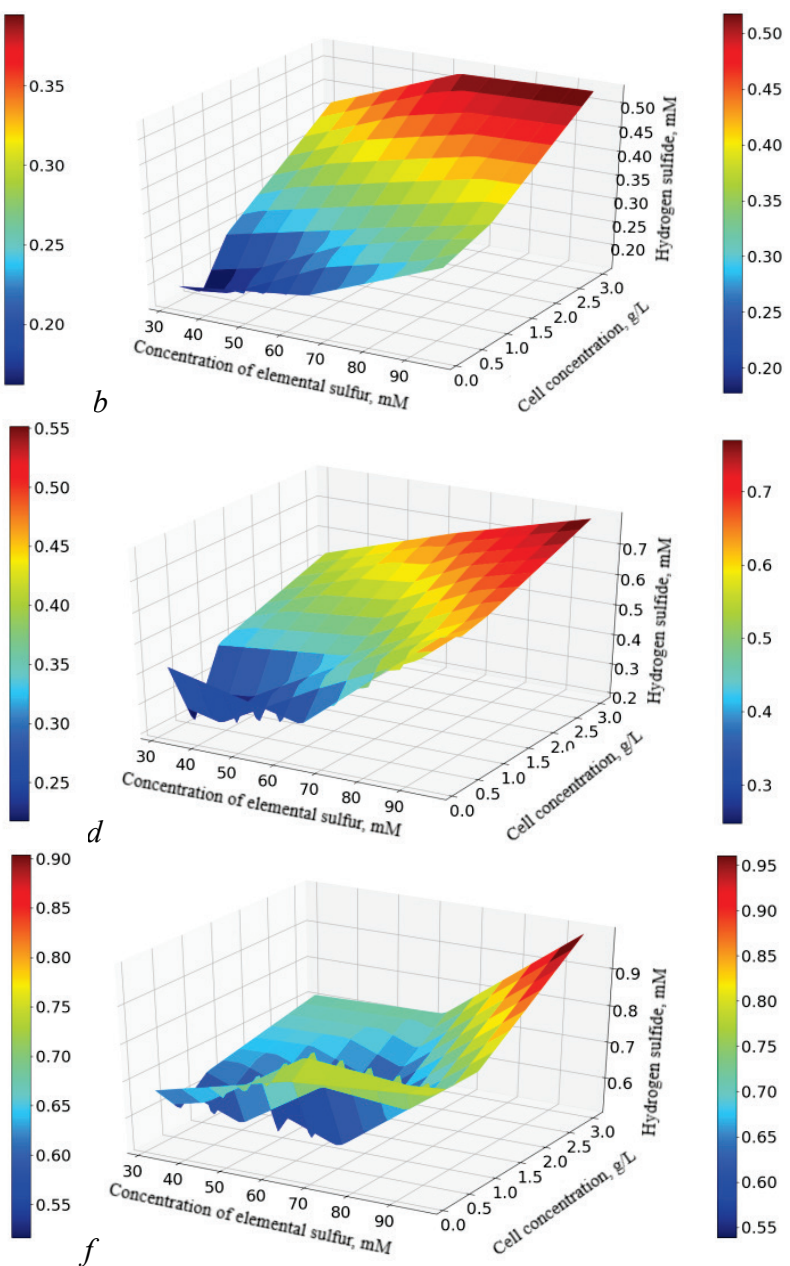

Fig. 5. The effect of different concentrations of elemental sulfur and different initial concentration of cells on the sulfidogenic activity of bacteria Desulfuromonas sp. YSDS-3 after 12 hours $(a), 1(b), 3(c), 5(d), 7(e), 16$ діб (f) of cultivation; $\mathrm{x} \pm \mathrm{SD}, \mathrm{n}=5$

\section{Discussion}

Sulfur-reducing bacteria are involved in the reduction deposition of highly toxic ions of metals in the process of reduction of elemental sulfur to hydrogen sulfide, oxidizing various organic compounds as well (An \& Picardal, 2015; Kefeni et al., 2017). In the previous studies, we found that bacteria Desulfuromonas sp. YSDS-3 in the presence of elemental sulfur use ethanol, propanol, butanol, sodium pyruvate, sodium acetate, sodium lactate, propionic, succinic, fumaric, malic acids, glucose, alanine, and casein as a carbon source. In the absence of elemental sulfur Desulfuromonas sp. YSDS-3 may use $\mathrm{Fe}$ (III), $\mathrm{Mn}(\mathrm{IV}), \mathrm{Cr}(\mathrm{VI}), \mathrm{NO}_{3}^{-}$, cysteine and malate as acceptors of electrons. Fumarate is used by Desulfuromonas sp.
YSDS-3 as a donor and acceptor of electrons (Chayka et al., 2016; Chayka et al., 2018).

Elemental sulfur is poorly soluble in water $\left(5 \mathrm{mg} / \mathrm{L}\right.$ at $\left.25^{\circ} \mathrm{C}\right)$; therefore, low sulfur bioavailability for sulfur-reducing bacteria may reduce the cost effectiveness of the sulfur reduction process for wastewater treatment (Zhang et al., 2018; Suna et al., 2020). The level of pH has a significant effect on the rate of hydrogen sulfide formation by sulfur-reducing bacteria (Suna et al., 2020). At the neutral $\mathrm{pH}$ value (7.0-7.5), elemental sulfur becomes bio-available; it dissolves in aqueous solution of hydrogen sulfide and goes into polysulfide (soluble form). At the acid $\mathrm{pH}$ values (less than 6.0) formation of polysulfide becomes limited; low solubility of elemental sulfur in water restricts its bioavailability and leads to the decre- 
ase in the rate of hydrogen sulfide formation (Suna et al., 2020). A sharp decrease in the sulfidogenic activity of bacteria Desulfuromonas sp. YSDS-3 at low $\mathrm{pH}$ values (5 and 4) can be possibly related to the fact that polysulfide saturation is reduced, and soluble sulfur goes into the elemental form (Fig. 1). The elemental sulfur concentration of up to $20 \mathrm{mM}$ is optimal for sulfur reduction by the bacteria Desulfuromonas sp. YSDS-3 (Fig. 2).

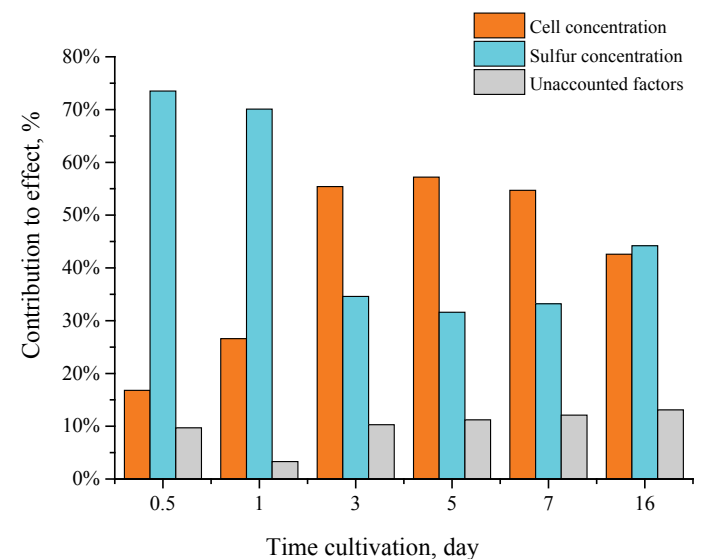

Fig. 6. Results of a two-way analysis of variance of the effect of different starting concentrations of elemental sulfur, different cell density and other unaccounted factors on the sulfidogenic activity

of Desulfuromonas sp. YSDS-3 during 16 days of cultivation

Hydrogen sulfide is one of the main factors that can limit growth of sulfur-reducing bacteria (Reis et al., 1992). According to the literature data, cyanobacteria are the most sensitive to hydrogen sulfide. The inhibiting effect of hydrogen sulfide was already manifested at its concentration from 13 to $60 \mu \mathrm{M}$ (Miller \& Bebout, 2004). Growth of sulfate-reducing bacteria $D$. desulfuricans Ya-11 was completely inhibited in the presence of $6 \mathrm{mM}$ sulfide in the medium. Addition of sulfide ion in the concentrations of 6.3 and $9.4 \mathrm{mM}$ to the medium of cultivation of bacteria being in the logarithmic phase of growth led to complete termination of the culture growth (Verkholiak \& Peretyatko, 2018). The most resistant among microorganisms to action of hydrogen sulfide are the archaea Methanocaldococcus jannaschii and Archaeoglobus profundus, which grow well at the optimum temperature of growth $\left(82{ }^{\circ} \mathrm{C}\right)$ at high enough concentrations of hydrogen sulfide -80 and $60 \mathrm{mM}$, accordingly (Lloyd et al., 2005). The bacteria Desulfuromonas sp. YSDS-3 under study are resistant to higher concentrations of hydrogen sulfide compared to sulfate-reducing bacteria. Growth inhibition was observed at hydrogen sulfide concentrations of 5-20 mM. The bacteria did not grow at a hydrogen sulfide concentration of $25 \mathrm{mM}$ and more (Fig. 3).

Among the most common environmental pollutants are compounds of hexavalent chromium, ferrum, nitrate and nitrite ions, etc. (Lovley et al., 2004; Owlad et al., 2009; Esther et al., 2015). It is known that sulfur-reducing bacteria in the absence of elemental sulfur reduce the metals of variable valency as electron acceptors and turn them into forms which are non-toxic or less toxic for living organisms (Lovley et al., 2004; An et al., 2015; Chayka et al., 2018). In the natural environments, where several potential electron acceptors are usually present at the same time, microorganisms initially use those that have the higher redox potential (Bertrand et al., 2014). It was established that presence of two acceptors of electrons ( $\mathrm{S}$ and $\mathrm{Cr}$ (VI), $\mathrm{S}$ and $\mathrm{MnO}_{2}, \mathrm{~S}$ and $\mathrm{Fe}$ (III) had no effect on the accumulation of biomass by the bacteria Desulfuromonas sp. YSDS-3 (Fig. 4). However, bacteria under such conditions accumulated 1.5-2.5 times less hydrogen sulfide than in the test medium. $\mathrm{Cr}$ (VI), $\mathrm{Fe}$ (III), $\mathrm{Mn}$ (IV), $\mathrm{NO}_{3}^{-}$were not detected in the culture medium. The simultaneous introduction of two electron acceptors elemental sulfur with $\mathrm{MnO}_{2}, \mathrm{KNO}_{3}$, iron (III) citrate and potassium bichromate - led to inhibition of sulfur reduction.

The effectiveness of microbiological deposition of metal ions by hydrogen sulfide, production of sulfur-reducing bacteria, depends on the concentration of $\mathrm{H}_{2} \mathrm{~S}$ (Gudz et al., 2011). It is known that the deposition of metal ions by hydrogen sulfide formed by sulfur-reducing bacteria is more cost effective in wastewater treatment compared to systems of sulfate ion treatment (Qiuet et al., 2017; Zhang et al., 2018; Suna et al., 2020). For evaluation of the efficiency of hydrogen sulfide production, the calculation of $\mathrm{C} / \mathrm{S}$ ratio ( $\mathrm{mg}$ of oxidized organic carbon to $\mathrm{mg}$ of sulfide formed) was made for sulfur-reducing bacteria Desulfuromonas sp. YSDS-3 and sulfate-reducing bacteria taken from the literature data (Dorosh et al., 2015; Qiuet et al., 2017; Verkholiak \& Peretyatko, 2018; Verkholiak \& Peretyatko, 2019). Low C/S ratio indicates the lower energy consumption for electron transfer from donor to elemental sulfur and formation of hydrogen sulfide (Table 1). In the presence of elemental sulfur, the C/S ratio is $0.212-0.241$, which is 2.5 times lower compared to sulfate-reducing bacteria Desulfomicrobium sp. CrR3, D. desulfuricans Ya-11. Therefore, hydrogen sulfide formation during sulfur reduction is a more energy efficient process than sulfate reduction for the purification of wastewater from heavy metal ions.

\section{Conclusions}

Different concentration of elemental sulfur has its effect on sulfidogenic activity and growth of bacteria Desulfuromonas sp. YSDS-3. The content of hydrogen sulfide grows with the increase in elemental sulfur concentration; maximum hydrogen sulfide concentration is $5.4 \mathrm{~mm}$. In the medium with polysulfide at the neutral $\mathrm{pH}$ value (7.5), bacteria produce hydrogen sulfide and accumulate biomass in the most effective way. When $\mathrm{pH}$ decreases to 5.0 and 4.0, sulfidogenic activity of bacteria is inhibited 3 and 7 times, accordingly.

Hydrogen sulfide at the concentration of $3 \mathrm{mM}$ does not inhibit the growth of bacteria; at the concentration of 5-20 mM it inhibits the accumulation of biomass 1.5 and 3.0 times, respectively. Bacteria did not grow at hydrogen sulfide concentration of $25 \mathrm{mM}$ and above. In the presence of elemental sulfur, the $\mathrm{C} / \mathrm{S}$ ratio is 2.5 times lower compared to sulfate-reducing bacteria (Desulfomicrobium $\mathrm{sp}$. CrR3, D. desulfuricans Ya-11). The elemental sulfur and initial cell concentration has the most significant effect on sulfidogenic activity of bacteria Desulfuromonas sp. YSDS-3.

\section{References}

Alves, A. S., Paquete, C. M., Fonseca, B. M., \& Louro, R. O. (2011). Exploration of the cytochromome of Desulfuromonas acetoxidans, a marine bacterium capable of powering microbial fuel cells. Metalomics, 3, 349-353.

An, T. T., \& Picardal, F. W. (2015). Desulfuromonas carbonis sp. nov., an Fe(III), $\mathrm{S}^{0}$ - and Mn(IV)-reducing bacterium isolated from an active coalbed methane gas well. International Journal of Systematic and Evolutionary Microbiology, 65(5), 1686-1593.

Bertrand, J. C., Bonin, P., \& Caumette, P. (2014). Environmental microbiology: Fundamentals and applications. Springer, Dordrecht.

Chayka, O., Peretyatko, T., Gudz, S., \& Halushka, A. (2016). Vykorystannia fumaratu bakteriiamy Desulfuromonas sp. [Utilization of fumarate by sulfur-reducing bacteria Desulfuromonas sp.]. Visnyk of Dnipropetrovsk University, Biology, Ecology, 24, 332-337 (in Ukrainian).

Chayka, O., \& Peretyatko, T. (2018). Vidnovlennia spoluk shestyvalentnoho khromu i nitratu bakteriiamy Desulfuromonas sp. YSDS-3, vydilenykh z gruntu Yazivskoho rodovyshcha sirky [The reduction of hexavalent chromoium and nitrates by Desulforomonas YSDS-3, isolated from the soil of Yasiv sulfur mine]. Ecology and Noospherology, 29, 76-82 (in Ukrainian).

Crane, E. J. (2019). Sulfur-dependent microbial lifestyles: Deceptively flexible roles for biochemically versatile enzymes. Current Opinion in Chemical Biology, 49, 139-145.

Dorosh, L. S., Peretyatko, T. B., \& Gudz, S. P. (2015). Zakonomirnosti vykorystannia sulfat- i nitrat-ioniv bakteriiamy Desulfomicrobium sp. CrR3 ta Desulfovibrio desulfuricans Ya-11 [The patterns of utilization of sulfate and nitrate ions by bacteria Desulfomicrobium sp. CrR3 and Desulfovibrio desulfuricans Ya-11]. Visnyk of Dnipropetrovsk University, Biology, Ecology, 6(2), 156-160 (in Ukrainian).

Esther, J., Sukla, L. B., Pradhan, N., \& Panda, S. (2015). Fe (III) reduction strategies of dissimilatory iron reducing bacteri. Korean Journal of Chemical Engineering, 32(1), 1-14.

Gudz, S. P., Peretyatko, T. B., Moroz, O. M., Hnatush, S. O., \& Klym, I. R. (2011). Rehuliuvannia rivnia sulfativ, sirkovodniu ta vazhkykh metaliv $\mathrm{u}$ tekhnohennykh vodoimakh sulfatvinovliuvalnymy bakteriiamy [Regulation of sulfates, hydrogen sulfide and hard metals level in technogenic reservoirs by sulfate reducing bacteria]. Mikrobiologichny Zhurnal, 73(2), 33-38 (in Ukrainian). 
Harris, D. S. (2003). Quantitative chemical analysis. Amazon, New York

Kefeni, K. K., Msagati, T. A. M., \& Mamba, B. B. (2017). Acid mine drainage: Prevention, treatment options, and resource recovery: A review. Journal of Cleaner Production, 151, 475-493.

Knoche, K. L., Renner, J. N., Gellett, W., Ayers, K. E., \& Minteer, S. D. (2016) A self-sufficient nitrate ground water remediation system: Geobacter sulfurreducens microbial fuel cell fed by hydrogen from a water electrolyzer. Journal of the Electrochemical Society, 163, 651-656.

Li, Y., Tang, K., Zhang, L., Zhao, Z., Xie, X., Chen, C. A., Wang, D., Jiao, N., \& Zhang, Y. (2018). Coupled carbon, sulfur, and nitrogen cycles mediated by microorganisms in the water column of a shallow-water hydrothermal ecosystem. Fronties an Microbiology, 9, 1-13.

Lloyd, K. G., Edgcomb, V. P., Molyneaux, S. J., Molyneaux, S. J., Böer, S., Wirsen, C. O., Atkins, M. S., \& Teske, A. (2005). Effects of dissolved sulfide, pH, and temperature on growth and survival of marine hyperthermophilic archaea. Appled and Environtal Microbiology, 71, 6383-6387.

Logan, B. E., \& Regan, J. M. (2006). Microbial fuel cells - challenges and applications. Environtal Science and Technology, 40, 5172-5180.

Lovley, R. D., Holmes, D. E., \& Nevin, K. P. (2004). Dissimilatory Fe (III) and Mn (IV) reduction. Advances in Microbial Physiology, 49, 219-286.

Miller, S. R., \& Bebout, B. M. (2004). Variation in sulfide tolerance of photosystem II in phylogenetically diverse cyanobacteria from sulfidic habitats. Appled and Environtal Microbiology, 70, 736-744.

Moroz, O. M., Hnatush, S. O., Tarabas, O. V., Bohoslavets, C. I., \& Yavorska, G. V. (2018). Sulfidohenna aktyvnist sulfatvidnovnykh ta sirkovidnovnykh bakterij za vplyvu spoluk metaliv [Sulfidogenic activity of sulfate and sulfur reducing bacteria under the influence of metal compounds]. Biosystems Diversity, 26, 3-10 (in Ukrainian).

Owlad, M., Aroua, M. K., Ashri, W., Daud, W., \& Baroutian, S. (2009). Removal of hexavalent chromium-contaminated water and wastewater: A review. Water, Air, and Soil Pollution, 200, 59-77.

Postgate, J. R. (1984). The sulfate-reducing bacteria. 2nd ed. Cambridge University, Cambridge.

Qiu, Y. Y., Guo, J. H., Zhang, L., Chen, G. H., \& Jiang, F. (2017). A high-rate sulfidogenic process based on elemental sulfur reduction: Cost-effectiveness evalua- tion and microbial community analysis. Biochemical Engineering Journa, 128, 26-32.

Reis, M. A., Almeida, J. S., Lemos, P. C., \& Carrondo, M. J. (1992). Effect of hydrogen sulfide on growth of sulfate reducing bacteria. Biotechnology and Bioengineering, 40, 593-600.

Richter, K., Schicklberger, M., \& Gescher, J. (2012). Dissimilatory reduction of extracellular electron acceptors in anaerobic respiration. Appled and Environtal Microbiology, 4, 913-921.

Smith, W. L., \& Gadd, G. M. (2000). Reduction and precipitation of chromate by mixed culture sulphate reducing bacterial biofilms. Journal of Appled Microbiology, 88, 983-991.

Sugiyama, M. (2002). Incassignee. Reagent composition for measuring hydrogen sulfide and method for measuring hydrogen. United States Patent 6,340,596 B1. 2002 Jan 22.

Suna, R., Li, Y., Lin, N., Ou, C., \& Wang, X. (2020). Removal of heavy metals using a novel sulfidogenic AMD treatment system with sulfur reduction: Configuration, performance, critical parameters and economic analysis. Environtal Internation, 136, 1-9.

Vasyliv, O. M., Maslovska, O. D., Ferensovych, Y. P., Bilij, O. P., \& Hnatush, S. O. (2015). Interconnection between tricarboxylic acid cycle and energy generation in microbial fuel cell performed by Desulfuromonas acetoxidans IMV B-7384. Proceedings SPIE, 9493, 94930J-1-7.

Verkholiak, N. S., \& Peretyatko, T. B. (2018). Morfofiziolohichni vlastyvosti sulfatvidnovliuvalnykh bakterii, vydilenykh iz systemy ochyshchennia stichnykh vod $\mathrm{m}$. Lvova [Morphophysiological properties of sulfate-reducing bacteria isolated from the system of Lviv wastewater treatment]. Microbiology and Biotechnology, 4, 19-29 (in Ukrainian)

Verkholiak, N. S., \& Peretyatko, T. B. (2019). Destruktsiia toluenu ta ksylenu sulfatvidnovliuvalnymy bakteriiamy [Destruction of toluene and xylene by sulfatereducing bacteri]. Ecology and Noospherology, 30(2), 95-100 (in Ukrainian).

Zhang, Z., Sun, R., Liang, S., Chen, G.-H., \& Jiang, F. (2018). Self-accelerating sulfurreduction via polysulfide to realize a high-rate sulfidogenic reactor for wastewater treatment. Water Research, 130, 161-167. 